\title{
Florida Landowner Incentive Program 1
}

\section{Florida Fish and Wildlife Conservation Commission and William M. Giuliano ${ }^{2}$}

\section{The purpose of the Florida Landowner Incentive Program is to improve habitat conditions for} threatened or endangered species on private lands.

Florida is recognized as one of North America's most important reservoirs of biodiversity. However, due to a surge in population growth and development, habitat loss in Florida is accelerating. This habitat loss has led to significant population declines in many species (Figure 1), including 110 vertebrate, 8 invertebrate, and 542 plant species.

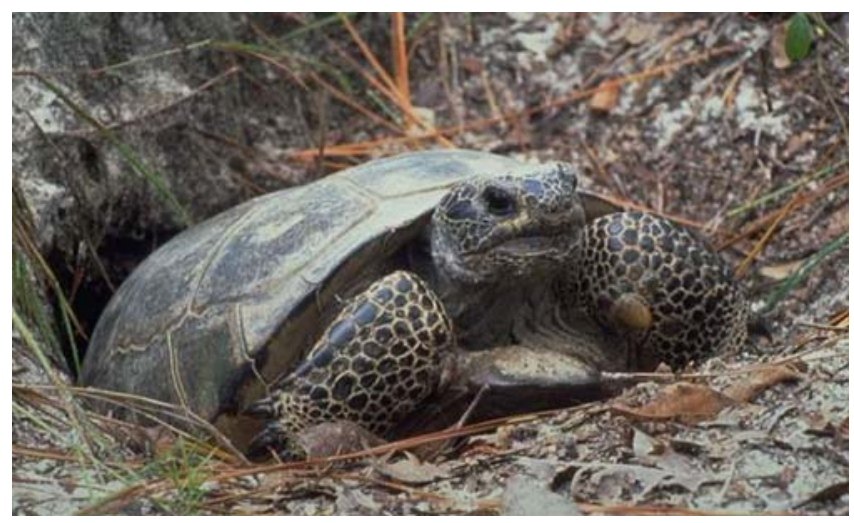

Figure 1. The gopher tortoise, a species at risk due to habitat loss. Credits: Florida Fish and Wildlife Conservation Commission. (2006).
The key to conserving these species involves maintaining or enhancing habitats that exist on private lands. Accordingly, the Florida Fish and Wildlife Conservation Commission (FWC) is working with private landowners to educate and encourage land management actions that will maintain or enhance habitat conditions that benefit at-risk species (Figure 2).

\section{Financial Assistance for Landowners}

The Landowner Incentive Program (LIP) is an annual competitive grant awarded by the U.S. Fish and Wildlife Service (FWS) through the Land and Water Conservation Fund. The program's main objective is to benefit both species at risk and associated habitat on private lands. Through this program, Florida's Fish and Wildlife Conservation Commission is working to provide science-based recommendations and financial assistance for conserving and enhancing the state's habitat resources on private lands.

To apply, interested landowners must complete a LIP application (see

1. This document is WEC 212 and one of a series of the Department of Wildlife Ecology and Conservation, Florida Cooperative Extension Service, Institute of Food and Agricultural Sciences (IFAS), University of Florida. First published: May 2006. Please visit the EDIS Web site at http://edis.ifas.ufl.edu for more publications. This article was adapted from www.myfwc.com/lip published by the Florida Fish and Wildlife Conservation Commission.

2. Florida Fish and Wildlife Conservation Commission, Landowner Incentive Program, PO Box 22105, Tampa, FL 33622-2105 (850-488-4676); and William M. Giuliano, Assistant Professor and Wildlife Extension Specialist, Department of Wildlife Ecology and Conservation, Cooperative Extension Service, Institute of Food and Agricultural Sciences, University of Florida, Gainesville, FL 32611.

The Institute of Food and Agricultural Sciences (IFAS) is an Equal Opportunity Institution authorized to provide research, educational information and other services only to individuals and institutions that function with non-discrimination with respect to race, creed, color, religion, age, disability, sex, sexual orientation, marital status, national origin, political opinions or affiliations. U.S. Department of Agriculture, Cooperative Extension Service, University of Florida, IFAS, Florida A. \& M. University Cooperative Extension Program, and Boards of County Commissioners Cooperating. Larry Arrington, Dean 


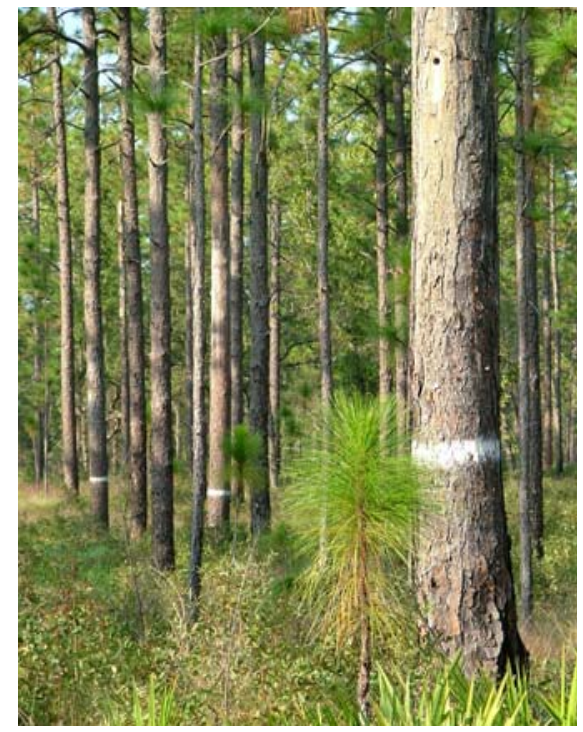

Figure 2. Properly managed forest ecosystems provide excellent wildlife habitat, while allowing landowners to meet other objectives such as timber production. Credits: Florida Fish and Wildlife Conservation Commission. (2006).

http://www.myfwc.com/lip/pdf/LIP_Application.pdf) that includes the enrolled property location, boundary, and proof of ownership. There are no acreage limitations and any private (non-governmental) landowner is eligible to receive up to $\$ 20,000$ in cost-shares for approved habitat improvement practices. Cost-shares require a 50\% non-federal match and are reimbursed based on established flat rates for each approved practice (see http://www.myfwc.com/lip/financial.htm).

Landowners will be reimbursed for approved practices based on extent completed, established cost-share rates, and invoices/receipts submitted by the landowner documenting expenditures. In compliance with practice standards, landowners will have twelve months to complete approved practices, with six-month extensions approved on a case-by-case basis.

\section{Property Scoring and Evaluation}

Funds are distributed to private landowners whose properties have the greatest potential benefits for imperiled species. To accomplish this task, the FWC is using a Geographic Information System (GIS) computer model to numerically rank properties (see http://www.myfwc.com/lip/scoring.htm). This computer model includes previously developed or recorded environmental information such as land cover imagery, currently listed species habitats, wildlife occurrence data, and potential listed species habitat models. Applications will be accepted on a continuous basis, evaluated for natural resource value, and ranked based on the resulting natural resource value score.

FWC biologists will conduct a primary needs assessment (initial site visit) to applicant properties according to rank, with high scoring properties receiving priority (Figure 3). FWC biologists can then recommend appropriate cost-sharing practices based on a combination of GIS analysis and site visitation (Figure 4).

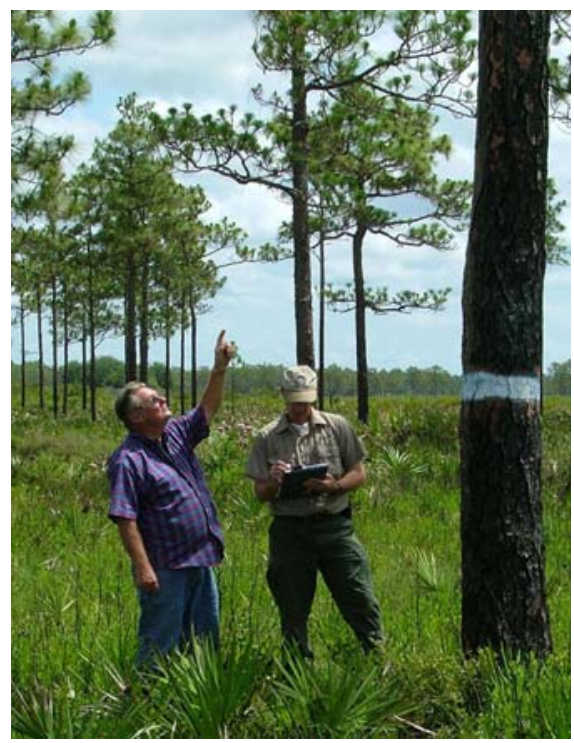

Figure 3. Project needs assessments will be conducted by Florida Fish and Wildlife Conservation Commission biologists on an applicant's property. Credits: Florida Fish and Wildlife Conservation Commission. (2006).

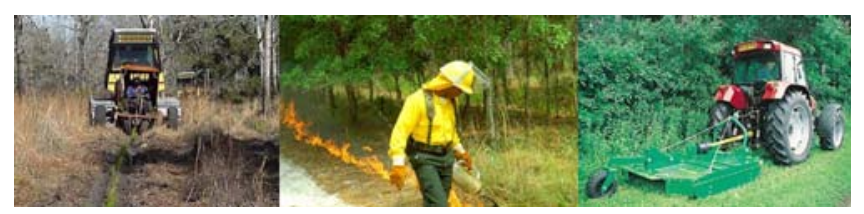

Figure 4. Landowners will be reimbursed for approved practices. Credits: Florida Fish and Wildlife Conservation Commission. (2006).

\section{For More Information on the Landowner Incentive Program or an Application}

http://www.myfwc.com/lip. 